\title{
Contractile System
}

National Cancer Institute

\section{Source}

National Cancer Institute. Contractile System. NCI Thesaurus. Code C13403.

Contractile system directs cell movement and is responsible for maintaining or changing cell shape. The system consists of many specialized cytoplasmic proteins, including actin, myosin, tubulin, kinesin, other cytoskeletal and contractile system proteins. ( $\mathrm{NCl})$ 